\title{
Göstergebilim Yaklaşımı Kapsamında Turizm Mitleri Üzerine Bir İnceleme
}

An Analysis on Tourism Myths Under Semiotic Perspective

\author{
Kübra AŞAN* \\ *Arş. Gör. Dr., Sinop Üniversitesi Turizm İşletmeciliği ve Otelcilik Yüksekokulu, 57000, Sinop, Türkiye. \\ E-posta: kubra.asan@hotmail.com \\ ORCID: 0000-0002-8739-3585
}

MAKALE BILGILERI

Makale işlem bilgileri:

Gönderilme tarihi: 7 Nisan 2021

Birinci düzeltme: 16 Ağustos 2021

İkinci düzeltme: 8 Ekim 2021

Üçüncü düzeltme: 3 Aralık 2021

Kabul: 11 Ocak 2022

Anahtar sözcükler: Turizm iletişimi,

Turizm pazarlaması, Turist davranıșı,

Göstergebilim, Turizm mitleri.

\section{ARTICLE INFO}

Article history:

Submitted: 7 April 2021

Resubmitted: 16 August 2021

Resubmitted: 8 October 2021

Resubmitted: 3 December 2021

Accepted: 11 January 2022

Key words: Tourism communication, Tourism marketing, Tourist behavior, Semiotics, Tourism myths.

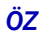

Mitler, ilkel dönemlerde olduğu gibi modern ve geç modern dönemde de olguların anlamlandırılması veya normalleştirilmesi için başvurulan bir dil biçimi olmuştur. Turizmle ilgili süreçlerin anlamlandırılmasında da mitler, epistemolojik bir perspektif ve yeni tartışma alanları açma potansiyeli taşır. Bu bağlamda çalışmada turizm mitleri üzerine genel bir kavramsal çerçeve sunmak amacıyla alanyazın taraması yapılmıştır. LéviStrauss'un derin yapısal karşıtlıklar temelinde mit çözümleme yaklaşımı takip edilerek turizmde göstergebilim çalıșmaları kapsamında bir derleme çalıșması gerçekleştirilmiştir. Çalıșmanın sonuçları turizm mitlerinin, eleştirel ve işlevsel bağlamlarda kavramsallaştırabileceğini ortaya koymaktadır. Eleştirel bağlamda turizm mitlerinde neoliberalizm, postkolonyalizm ve neokolonyalizm ideolojileri öne çıkmaktadır. isşlevsel bağlamda ise turistik deneyim ve destinasyonların tutundurulmasında bir pazarlama dili olarak mitlere bașvurulduğu görülmektedir. Çalıșma sonuçlarının turizm mitlerinin kavramsallaştırılması ve turizm araştırmalarında gösterge ve mitlerin çözümlenmesi konularında alanyazına katkı sağlaması beklenmektedir.

\section{GiRiş}

Insanlar tarih boyunca nesne ya da olayları anlamaya ve anlamlandırmaya ihtiyaç duymuştur. Mitler, gerçekliğin ya da doğanın görünümlerinin anlaşılmasında önemli bir referans olagelmiştir. İlkel mitlerin esas işlevi, yaşam ve ölüm, iyi ve kötü, doğa ve kültür gibi ikilikler üzerine kurulu anlamlandırmalarla, olay ve olguların doğallaştırılmasını sağlamaktır (Lévi-Strauss 2013). Modern dünyada da kitlelerin belli bir durumu normalleştirmesi ve kabullenmesini sağlayacak şekilde kitle iletişim araçlarıyla çeşitli ideolojilerin yerleştirildiği modern mitler yaratılabildiği görülmektedir (Barthes 2003). Bu yaklaşımı takiben pek çok araştırmada, neoliberalizmle birlikte yükselen yoğun tüketim hareketini desteklemede mitlere başvurulduğu, insanların tüketimi doğallaştırması ve daha çok tüketime yönelmesini teşvik edecek reklam tasarımları yapıldı ̆̆ı raporlanmıştır (Chapman 1979; MacCannell 1987; Dağtaş 2012; König vd. 2016).

Turizm yoğun iletişim gerektiren, sosyal ve kültürel bir pratik olmanın yanı sıra modern ve postmodern bir olgu olarak kavramsallaştırılır (Urry 2009; Berger 2011). Dolayısıyla her bir turizm aktörü arasında kurulan iletişimde sembo- 
lik anlamlandirmalara dayanan mitlere rastlamak mümkündür. Örneğin tarihi kültürel miras alanlarında ulusalcılık ideolojisinin mitleştirildiğini görmek mümkündür (Knudsen vd. 2014). Bir başka örnek, gerçekte yarattıkları sonuçların sürdürülebilirlik ile çelişmesi bağlamında ekoturizm ya da yeşil işletmeciliğin bir mite dönüşebileceğidir (Erdoğan 2010; Sharpley 2010).

Turizmde mitlerin incelendiği çalışmalar oldukça sınırlıdır. Oysa mitler geçmişe, bugüne ve geleceğe ilişkin yorumlara kaynaklık edebilir (Lévi-Strauss 1962). Mitler, çelişik bir durum ya da bir kandırmacadan çok daha geniş ve zengin anlamlara sahiptir ve derin sosyal yapilarla ilgilidir (Fiske 1996). Bu bağlamda sosyal bir olgu olarak turizmin incelenmesinde mitsel çözümlemeler yeni epistemolojik tartışmalar açabilir. Bununla beraber sıklıkla neoliberal hedeflerle yaratılan modern tüketim mitlerinin olumsuz anlamlarının aksine mitlerin farklı anlamları da sorgulanabilir. Örneğin turizmin kendi doğasına bağlı olarak turist psikolojisi (Bennet 2013; Gros 2017) ve destinasyon geliştirme (Dallabona 2015) gibi konularda mitlerin olumlu işlevsel anlamları da söz konusudur.

Turizmde mitlerin nasıl çözümlenebileceği ve mitlere ilişkin nasıl çıkarımlar yapılabileceğine ilişkin bir temele ihtiyaç olduğu açıktır. Bu ihtiyaçtan hareketle çalışma, turizm mitlerini açıklamayı ve tartışmaya açmayı amaçlamaktadır. Mitlerin sistemli bir şekilde analiz edilmesi için göstergebilim yöntemi başvuru kaynağı olabileceğinden hareketle çalışmada turizm alanında bu yöntemin kullanıldığı çalışmalar çerçevesinde incelemeler yapılmıştır. Bu doğrultuda alanyazın taraması yöntemine başvurulmuş ve bir derleme çalışması gerçekleştirilmiştir. Tarama sonucunda ulaşılan çalışmalarda ifade edilen turizm mitleri, Lévi-Strauss'un önerdiği yapısal karşıtlıklar kapsamında irdelenmiştir. Çalışma sonuçlarının turizm mitlerinin kavramsallaştırılmasına hizmet etmesi hedeflenmektedir.

\section{KAVRAMSAL ÇERÇEVE}

Çalışmanın amacı doğrultusunda gerçekleştirilecek alanyazın taramasından önce mit kavramının açıklanmasında fayda vardır. Bu bağlamda devam eden bölümde sosyal bilim bakış açısıyla mit ve mit çözümlerine ilişkin genel bir açıklama sunulmaktadir. Daha sonra turizm alanındaki mitlere ilişkin kuramsal temellere yer verilmiştir.

\section{Mitler Üzerine}

Türk Dil Kurumu'na (2021) göre mitler, "geleneksel olarak yayılan veya toplumun hayal gücü etkisiyle biçim değiştiren alegorik bir anlatımı olan halk hikâyesi, mitos" şeklinde tanımlanmakla birlikte mecazen "efsaneleşen kavram ve kişi” ş̧eklinde de açıklanmaktadır. Bu çalışmada, sosyolojik ve iletişimsel bir olgu olarak ele alınan mitlerin ikinci anlamına odaklanılmıştır. Nitekim mitler tarih boyunca insanlığa eşlik ederek sadece olguları değil, davranışlar ve değerleri içeren gelenekleri de açıklamaktadır (König vd. 2016). Mitler, mistik ve kozmolojik olayları açılamanın yanı sıra belirli bir toplumsal düzeni ve birey davranışlarını destekleyen sosyal ve psikolojik işlevlere sahiptir (Campbell 1991). Ayrıca Malinowski'e (1926) göre mitler, bir inancı dile getirir, güçlendirir ve düzenler; ahlakın koruyuculuğunu yaparak yürürlükte kalmasını sağlar, insanların idaresi için pratik kurallar getirir.

Mit denildiğinde akla ilk gelen isimlerden biri olan Lévi-Strauss (1962) Yaban Düşünce isimli kitabında ilkel mit çözümlemelerinde göstergebilime başvurmuştur. $\mathrm{O}$ dönem dilbilimcilerin kullandığg göstergebilime, bir antropoloji çalışmasında başvuran Lévi-Strauss, kültürün de tıpkı dil gibi semboller bütünü olduğunu ve göstergebilim yöntemiyle çözümlenebileceğini göstermiştir (aktaran Yücel 2005). Lévi-Strauss'a göre mit, derin yapısal ikili karşıtlıklar üzerine kurulu bir öyküdür. En güçlü ve en önemli mitler endişe giderici işlev görürler; herhangi bir ikili karşıtlık yapısında doğal olarak var olan çelişkilere değinirler, bunları tam olarak çözemeseler de bunlarla yaşamanın yollarını gösterirler (Fiske 1996).

Lévi-Strauss, Kuzey Amerika Miti ile çözümlemesini örneklendirmektedir. Bu mitte çok şiddetli ve soğuk olan, estiğinde yaşamı durma noktasına getiren kötü karakter Güney Rüzgârıdır. Anlatıya göre bu rüzgârı yakalayabilen, uysallaştırabilen ve yaşamı yoluna koyan bir folya (vatoz) balığıdır. Bu mit doğanın dost ve düşman 
yanları arasındaki karşıtlığı ele almaktadır. LéviStrauss'a göre bu mitte bir folya (vatoz) balığının seçilmesinin nedeni, balığın şekli ve rüzgârın varlıksal değişimi arasındaki benzerliktir. Folya balığına yandan bakıldığında neredeyse görünmez iken üstten bakıldığında çok büyüktür. Somutlama mantığına göre folya balığı, dost ve düşman doğa arasındaki karşıtlığı, rüzgârın varlık ve yokluğunu somutlaştırır ve bunlar arasında aracılık yapmaktadır (Fiske 1996). Bu mit, insanın yaşamını sürdürürken doğanın getirdiği zorlukları normalleştirme ve kabullenme sürecinde mitlerin çelişki giderici işlevine güzel bir örnek teşkil etmektedir. Bu örnekte olduğu gibi pek çok mitte doğa/kültür, ölüm/yaşam, vahşi/ evcil, eril/dişil gibi karşıtlıklar temelinde mitlerin endişe giderici işlevlerle temellendirildiğ $i$ söylenebilir. Nitekim önde gelen göstergebilimcilerden Greimas'a (1989) göre de anlamlandırma, farklılıklar ve benzerliklerin algılanması ile gerçekleşmektedir.

Lévi-Strauss'un çalışmaları, göstergebilim kavramlarıyla ilkel mitlerin işleyişini ortaya çıarmış ve modern mitlerin çalışılmasına öncülük etmiştir (Dağtaş 2012). Bunu izleyen Barthes (2003), mit kavramının yer aldığı bir gösterge modeli geliştirerek, sadece ilkel toplum kültürlerinin değil, modern toplum kültürlerinin de kendine has mitler oluşturabildiğini öne sürmüştür. Doğa ve kültür arasındaki ilişkinin karmaşık bir ürünü olan mit, Barthes'a göre bir şey üzerinde düşünme, onu kavramsallaştırma ya da anlamanın kültürel yoludur. Barthes (2005) anlamlandırma$\mathrm{y} 1$, düzanlam ve yananlam olmak üzere iki boyutta incelediği bir gösterge modeli sunar. Düzanlam, göstergenin göstereni ve gösterileni arasındaki ilişkiyi ve gösterenin dişsal gerçeklikteki göndergesiyle ilişkisini içermektedir. Gönderge, daima gerçek dünyada bir sözcük ya da kavramın işaret ettiği fiili veya bir şeyi ifade etmektedir ve dişsaldır. Yananlam ise göstergenin, kullanıcıların duyguları heyecanları ve kültürel değerleriyle buluşması sonucunda meydana gelen etkileşimi betimlemektedir (Fiske 1996). Modele göre yananlamın göstereni, düzanlamın göstergesidir; yananlamın gösterileni ise mittir.

Barthes mitleri, ideoloji kavramıla açıklamaktadır. Bu açıklama, yapısalcı Marksist düşünür Althusser'in mitleri, üretim ilişkileri, sınıflar arası ilişkiler ve insanların yaşadı $\breve{g}_{1}$ dünya ile ilişkilerini yeniden üretmek üzere işleyen, yayılmış bir pratikler bütünü olarak tanımlamasına dayanmaktadır (Dağdaş 2012). Bu bağlamda Barthes'a göre, kitle iletişim araçlarıyla hâkim sınıfın çıkarına olan ideolojiler mitleştirilerek doğallaştırılmaktadır. Dolayısıyla Barthes tarihsel bir mit çözümlemesi yanında, modern mitlerin, tüketime yönelik yeni dünya sisteminin temel değerlerini meşrulaştırma işlevi yürüttüğünü öne sürer (Horzum 2011).

Barthes' 1 takip eden çalışmalarda reklamların, kültürel öğeler ve değerlere paralel olarak mitleri de kullandığı desteklenmektedir (König vd. 2016). Modernizmle beraber ortaya çıan yeni ürün ve hizmet yelpazesi, çok çeşitli yaşam tarzlarını mitleştirmekte, reklamlarda bu yaşam tarzlarına ulaşmanın yolunun o ürünü satın almak olduğu gösterilmektedir (Horzum 2011). Mitsel olarak reklamlar; sınıfsal çelişkileri çözmekte, tüketimcilikle kimlik modelleri sunmakta ya da var olan toplumsal düzeni onaylamaktadır. Özetle reklamlarda kapitalist değerleri ve kapitalist ideolojinin doğallaştırılıp meşrulaştırıldığ 1 yorumuna ulaşmak mümkündür (Barthes 2005).

Barthes'ın çalışmalarındaki temel prensip; kitle kültürü içinde eleştirel olarak bir pozitif-negatif ayrımı yapmak yerine, modern toplumlarının örf, adet ve geleneklerinin nasıl zaman içerisinde "doğallaşıp" mite dönüştügünü ortaya koymaktır. Her ne kadar daha sonra postmodernizme yaklaşarak, mitleri bir moda sistemi içinde açılamaya yönelmiş olsa da Barthes, kültürel eleştirinin yöntemsel bir aracı haline gelen mit yaklaşımıyla alanyazında önemli bir yer edinmiştir (MacCannell 1987; Dağtaş 2012). Mitlerin bilimsel yorumu veya çözümlenmesi, edebiyat kura$\mathrm{mi}$, psikanaliz, teoloji, sosyal antropoloji, halkbilim ve hatta tarihe uzanan bir yelpazede disiplinler arası bir sosyal bilim düşüncesinin somutlaştığı anahtar alanlardan biridir (Parladır 2006). Turizmde ise göstergebilim çalışmaları olmasına rağmen mitlere odaklanan çalışmaların sayısı sinırlidır.

\section{Turizmde Mitler}

Turizmde modern mitlere ilişkin ipuçları sunan ilk makalelerden biri Urbain'e (2009) aittir. Ar- 
tan turizm hareketliliğiyle turizmde özgünlük tartışmalarının başladığ 1 yıllarda Urbain (2009) turizmde sahtelik problemi yaşandığına dikkat çekmektedir. Buna göre hakiki/özgün turistik sunumlar ve özgün olmayan/sahte turistik sunumlar sorun teşkil etmektedir. Bu karşıtlıklar karşısında turistin gerçek olanı bulması çok önemlidir. Tam da bu noktada Urbain (2009) turizm pazarlamasında bu çelişkiyi giderecek bir çözüm olarak turizm reklamlarında keşfetme deneyimlerinin yüceltilerek sunulduğunu anlatır. Buna göre turizm pazarlaması uygulamalarında turistlere sahtelik probleminin üstesinden gelecek şekilde "hakiki" yolculuk imgesinin yerleştirildiği içerikler sunulmakta, turistlerin bunu keşfetmesi vaat edilmektedir.

Frederic Gros (2017), Yürüyüşün Felsefesi isimli kitabında, hac yolculuklarının ardında yenilenme ve arınma miti yattığına dikkat çekmektedir. Yazara göre hacılığın mistik ideali olarak bireyler, yolculuktan değişmiş olarak dönmeyi umut eder. Dahası kutsal mekanların yakınlarında arınmayı sağlayan, akarsu veya nehir gibi bir doğal kaynak vardır. Hinduların her yıl Ganj Nehri'nde yıkanmalarını örnek veren Gros, hacıların temizlenmek, kendilerinden arınmak adına suya girdiklerinden bahseder. Bu noktada erken dönem turizm kuramlarında Victor Turner'ın (1969) hacılık yaklaşımını hatırlamakta fayda vardır. Turner'a göre turistler, hacılar gibi alışık olunan yerden uzak bir yere hareket eder ve eşiksel (liminality) deneyimler yaşar. Eşiksellik karnavallar, hacılık, ergenliğe geçiş törenleri ya da olağan durumların dışına çıkıldığı ritüeller gibi "sınırda olma" anlarından bahsetmek için kullanılan, zaman ve mekân dışındaki bir karşıt yapı içinde bulunmayı ifade eder (Urry 2009). Benzer şekilde Tresidder (2011), Durkheim'in kutsal ve dünyevi (sacred/profane) karşıtllı̆g temelinde turizm pazarlamasında turistik değerlerin, kullanılan göstergelerle kutsallaştırıldığına dikkat çekmektedir. Doğa yürüyüşünün sembolik anlamlarına odaklanan Gros (2017) yürüyüşleri hacılık deneyimine benzetmekte, doğa yürüyüşlerinin hac yolculuklarında olduğu gibi doğal kaynaklara yakın, bir değişim süreci ve arınma hissi barındıran etkinlikler olduğunu ifade etmektedir. Buradan hareketle yalnızca hac yolculukları de- ğil, doğa yürüyüşlerine ilişkin anlatının, ölüm/ yaşam, kutsal olmayan/kutsal, fani/ebedi gibi ikilikler içerisinde arabuluculuk yaptığı söylenebilir. Sonuç olarak Gros (2017), doğa yürüyüşlerini kutsallaştırmakta, yüceltmekte, bireylerin varoluşsal kaygılarını giderecek mitsel bir değere sahip olduğuna işaret etmektedir.

Kültürel sosyoloji profesörü Andy Bennett (2013) turizm deneyimlerinin anlamlandırılmasinda film ve müzik endüstrisinin etkisini ele almıştır. Bu endüstriler tarafından çeşitli semboller üretilerek tüm dünyada destinasyon imajları geliştirilebilmektedir. Örneğin kültür endüstrisinde orijinal bir Blues müzik deneyimi yaşama olanağı olarak, Chicago'da klasik kulüplere gitme ve yerinde deneyim yaşama vaat edilmektedir. Buradan hareketle kültür endüstrileri bağlaminda turistik deneyimlerinin mitleştirilebildiği söylenebilir.

Sharpley (2010) küçük ölçekli, yerelden yönetim, kontrol edilebilir düşük olumsuz etkiler, uzun vadeli hedefleri içeren bütünsel yaklaşım gibi ilkelerle 1990'lı yıllardan günümüze sıklıkla başvurulan sürdürülebilir turizm uygulamalar1nı eleştirmektedir. Yazara göre turizmin parçalı yapısı, turizm işletmelerinin kısa dönemli hedefleri, turizm çeşitlendirilmesi için şart olan eşitsizlikler gibi özellikleri nedeniyle geniş kapsamlı sürdürülebilir bir turizm gelişimi ancak teoride kalmakta ve görgül olarak sürdürülebilirliğin kanıtlanması güçleşmektedir. Temelde kârı en üst düzeye çıkarmak için sözde yeşillenen işletmeleri örnek gösteren Sharpley (2010), sürdürülebilir bir turizm gelişiminin ancak efsanede kaldığını, bir başka ifadeyle mitleştirildiğini ifade etmektedir.

Erdoğan'ın (2010) ekoturizm ve sorumlu turist uygulamalarına dair tespitlerinin yer aldı $\breve{g}_{1}$ çalışma da sürdürülebilirliğin mitleştirilebildiğini desteklemektedir. Erdoğan’a (2010: 69) göre ekolojik sürdürülebilirlik çerçevesine oturtulmuş ekoturizm; kırsal ve doğal alanlarda etki ve faaliyet alanını genişleterek turizm endüstrisinin, kitle pazar tüketimciliği ve bağımlılığ 1 artıran, yerli yaşam formlarını ve ekolojik bütünlügü yok eden bir pazar politikasına dönüşebilmektedir. Erdoğan'ın (2010) savını desteklediği örnekler- 
den biri de, ekoturistlerin çevre bilinci ve sorumluluğuyla hareket ettiği ve iyi niyet sahibi olduğu mitidir. Erdoğan'a göre çoğunlukla öz tatmin ve hazcı deneyimler peşinde olan ekoturistler, bölgenin kültürü ve doğa tarihi ile yakından ilgilenmemektedir. Özetle çalışmaya göre ekoturizm uygulamaları neoliberal harekete hizmet etmek üzere çok sayıda mit oluşturmaktadır. Sharpley (2010) ve Erdoğan'ın (2010) çalışmaları oldukça paralel olmakla birlikte Erdoğan, sürdürülebilir turizme ilişkin mitlerin ardında neoliberal bir ideolojik yerleştirme olduğunu açıkça ifade etmektedir.

Lyons vd. (2012) gönüllü turizm uygulamalarına ilişkin benzer bir bakış sunmaktadır. Çalışmada yazarlar gönüllü turizm yoluyla kültürleraraSı anlayış ve karşılıklı saygının artacağı fikrinden yola çıkarak gönüllü turizm deneyimlerinin, diğer kültürlerin daha az ırkçı veya klişeleşmiş bir şekilde algılanması için temel olup olmayacağını sorgulamışlardır. Çalışmada gönüllü turizmin, turistlerin dünya ve öteki hakkındaki görüşlerini değiştirebileceği fikrinin mitsel bir söylem olduğu ileri sürülmekte, büyük tur operatörleri ve kâr hedefleriyle yürütülen gönüllü turizm uygulamalarının neoliberal piyasalara bağlı olduğu ifade edilmektedir. Dahası gönüllü turistleri yönlendiren, iyi durumda olmayan/ötekine yardım etmek fikrinin neoliberalizm tarafından yönlendirilen eşitsizlikleri var etmeye devam ettiği belirtilmektedir.

Alanyazında her ne kadar turizm mitlerine ilişkin ipuçlarına ulaşılsa da sistematik olarak turizm mitlerini analiz eden çalışmalar oldukça sınırlıdır. Bu noktada göstergebilim izlenecek bilimsel bir yöntem olabilir. Araştırmanın devam eden bölümünde doğrudan ve sistemli bir mit analizi içeren göstergebilim çalışmalarına odaklanılmaktadır.

\section{INCELEME YAKLAŞIMI}

Çalışmada turizmde göstergebilim araştırmalarında konu edilen mitleri incelemek üzere alanyazın taraması yapılmıştır. Web of Science platformunda 01 Ağustos 2021 tarihinde "tourism myth" anahtar kelimesiyle yapılan tarama sonucunda 301 çalışmaya ulaşılmıştır. Araştırma kapsamına alınacak çalışmalar için iki ölçüt belirlenmiştir. Bunlar (1) göstergebilim yönteminin kullanılmış olması ve (2) modern veya postmodern mitlerin konu edilmesidir. Bu ölçütleri karşıllayan sadece dokuz çalışma tespit edilmiş ve araştırma bu çalışmalar üzerinden yürütülmüştür.

Çalışmada, belirlenen makaleler LéviStrauss'un yaklaşımı izlenerek incelenmiştir. Bu yaklaşım araştırmalarda incelenen turizm mitlerini sistemli bir çerçevede sunmayı mümkün kılmıştır. Bir önceki bölümde Kuzey Amerika Miti örneğinde açıklandığı gibi Lévi-Strauss mitleri derin yapısal karşıtlıklar ve somutlaştırma temelinde açıklamaktadır. Mitler, bu yapısal karşıtlıklar arasında yaşanan çelişkileri gideren ve doğallaştıran somut çözümler sunar (Fiske 1996). Buna göre "yapısal karşıtlıklar", "somutlaştırma" ve "mit" bileşenleri kapsamında çözümleme yapılabilir. Bu çalışmada da araştırma kapsamına alınan makalelerin bulguları ve sonuçları incelenmiş ve Lévi-Strauss modeline göre betimlenmiştir. İlk olarak incelenen makalelerde ulaşılan göstergeler temelinde yatan derin yapısal karşıtlıklar sıralanmıştır. Daha sonra bu karşıtlıklar arasındaki çelişkiyi gideren, somut çözümler üreten bir etkinlik ya da zihin durumu olarak işaret edilen turistik eylemler kaydedilmiştir. Çalışma bulguları tablo halinde (Tablo 1) sunulmuştur.

\section{BULGULAR VE TARTIŞMA}

Çalışma kapsamında incelenen makalelere ilişkin bulgular Tablo 1'de gösterilmektedir. Tabloda ilk olarak incelenen makalelere ilişkin tanımlayıcı bilgiler (kaynak, araştırmanın uygulama kapsamı, araştırmanın ilgili olduğu turizm boyutu) yer almaktadır. Daha sonra Lévi-Strauss modeline göre incelenen makalelerin bulguları üzerinde yapılan mit çözümlemesi, derin yapısal karşıtlıklar, somutlaştırma ve mit başlıkları altında tabloda sunulmuştur. Son olarak makalelerin turizm mitlerine bakış açıları değerlendirilerek ulaşılan çıarımlar eleştirel ve işlevsel olma durumlarına göre "yaklaşım" adı altında tanımlanmış ve tabloya eklenmiştir.

İlk olarak tabloda yer alan mitlerin işlevselliğine dikkat çeken çalışmalar değerlendirildiğinde, Johns ve Clarke'in (2001) çalışması mitlerin tu- 
Tablo 1. Turizm Mitleriyle İlgili Çalışmalar

\begin{tabular}{|c|c|c|c|c|c|c|c|}
\hline \multicolumn{3}{|c|}{ Araştırma bilgileri } & \multicolumn{4}{|c|}{ Mit çözümlemesi (Lévi-Strauss) } & \multirow[t]{2}{*}{ Yaklaşım } \\
\hline Kaynak & Kapsamı & $\begin{array}{c}\text { İlgili Turizm } \\
\text { Boyutu }\end{array}$ & \multicolumn{2}{|c|}{ Derin yapısal karşıtlıklar } & Somutlaştırma & Mit & \\
\hline Hopkins (1998) & $\begin{array}{l}\text { Huron Gölü/Kanada } \\
\text { tanıtım materyalleri }\end{array}$ & $\begin{array}{l}\text { Destinasyon, } \\
\text { Kırsal turizm, } \\
\text { Turist davranışı }\end{array}$ & $\begin{array}{c}\text { Kent } \\
\text { Yapay çevre } \\
\text { Toplum } \\
\text { Hızlı } \\
\text { Yerel olmayan }\end{array}$ & $\begin{array}{l}\text { Kır } \\
\text { Doğal çevre } \\
\text { Topluluk } \\
\text { Yavaş } \\
\text { Yerel } \\
\end{array}$ & $\begin{array}{l}\text { Huron Gölü'nde } \\
\text { kırsal turizme } \\
\text { katılmak }\end{array}$ & $\begin{array}{c}\text { Özgün kırsal } \\
\text { turizm deneyimi } \\
\text { miti } \\
- \\
\text { Tüketim miti }\end{array}$ & Eleştirel \\
\hline $\begin{array}{l}\text { Johns ve Clarke } \\
\text { (2001) }\end{array}$ & $\begin{array}{l}\text { İngiltere Norfolk } \\
\text { Broads tekne } \\
\text { gezileri ziyaretçi } \\
\text { deneyimleri }\end{array}$ & $\begin{array}{l}\text { Turist davranışı, } \\
\text { Tekne turizmi }\end{array}$ & $\begin{array}{c}\text { Sıradan } \\
\text { Aynılık } \\
\text { Şehir } \\
\text { Sıkıcı } \\
\text { Pasif deneyim }\end{array}$ & $\begin{array}{c}\text { Sıra dışı } \\
\text { Farklılık } \\
\text { Doğa } \\
\text { Eğlenceli } \\
\text { Aktif deneyim }\end{array}$ & $\begin{array}{c}\text { İdeal tekne } \\
\text { deneyimlerini vaat } \\
\text { eden tekne } \\
\text { turlarına katılmak }\end{array}$ & $\begin{array}{l}\text { İdeal tekne } \\
\text { deneyimi miti }\end{array}$ & İşlevsel \\
\hline $\begin{array}{l}\text { Waitt ve Head } \\
\qquad(2002)\end{array}$ & $\begin{array}{l}\text { Avustralya/ } \\
\text { Kimberley'e ait } \\
\text { kartpostallar }\end{array}$ & $\begin{array}{l}\text { Destinasyon, } \\
\text { Turist davranışı, } \\
\text { Yerel halk }\end{array}$ & $\begin{array}{l}\text { İnsan } \\
\text { Uygar } \\
\text { Toplum } \\
\text { Yakın } \\
\text { Merkez } \\
\text { Mülkiyet } \\
\text { Sömüren }\end{array}$ & $\begin{array}{l}\text { Hayvan } \\
\text { Vahşi } \\
\text { Doğa } \\
\text { Uzak } \\
\text { Sınır } \\
\text { Sahipsiz } \\
\text { topraklar } \\
\text { Sömürülen }\end{array}$ & $\begin{array}{l}\text { Bir destinasyon } \\
\text { olarak otantik } \\
\text { Kimberley } \\
\text { temsilleri } \\
- \\
\text { (Aslında } \\
\text { Aborijinlere ait } \\
\text { olan) sahipsiz } \\
\text { topraklar algısı } \\
\text { yaratılması } \\
\end{array}$ & $\begin{array}{c}\text { Son sınır (frontier) } \\
\text { destinasyon miti } \\
- \\
\begin{array}{c}\text { Neokolonyalizm } \\
\text { miti }\end{array}\end{array}$ & Eleştirel \\
\hline Nelson (2005) & $\begin{array}{c}\text { Greneda turistik } \\
\text { tanıtım materyalleri }\end{array}$ & Destinasyon & $\begin{array}{l}\text { Öteki olmayan } \\
\text { Tanıdık } \\
\text { Yapay } \\
\text { Pasif deneyim }\end{array}$ & $\begin{array}{c}\text { Öteki } \\
\text { Egzotik } \\
\text { Doğal } \\
\text { Aktif deneyim }\end{array}$ & $\begin{array}{c}\text { Greneda'yı ziyaret } \\
\text { etmek }\end{array}$ & $\begin{array}{c}\text { Greneda otantik } \\
\text { turizm deneyimi } \\
\text { mitleri }\end{array}$ & İşlevsel \\
\hline Kane (2013) & $\begin{array}{l}\text { Yeni Zelanda'da } \\
\text { bungy jumping } \\
\text { yapan öncü } \\
\text { maceracılar }\end{array}$ & $\begin{array}{l}\text { Turist davranışı, } \\
\text { Macera turizmi }\end{array}$ & $\begin{array}{c}\text { Tanınmayan } \\
\text { Çekimser } \\
\text { Sıradan } \\
\text { İmkânsız } \\
\text { Talihsiz macera }\end{array}$ & $\begin{array}{c}\text { Tanınmış } \\
\text { Meydan okuyan } \\
\text { Sıra dışı } \\
\text { Mümkün } \\
\text { Erişilebilir } \\
\text { macera }\end{array}$ & $\begin{array}{l}\text { Öncü } \\
\text { maceracıların } \\
\text { varlı̆ı ve } \\
\text { temsilleri }\end{array}$ & $\begin{array}{c}\text { Erişilebilir macera } \\
\text { miti }\end{array}$ & İşlevsel \\
\hline $\begin{array}{l}\text { Knudsen, vd. } \\
(2014)\end{array}$ & $\begin{array}{c}\text { Danimarka'daki } \\
\text { Frederiksstaden } \\
\text { bölgesi Amalienborg } \\
\text { Sarayları }\end{array}$ & $\begin{array}{l}\text { Destinasyon, } \\
\text { Kültür turizmi }\end{array}$ & $\begin{array}{c}\text { Danimarka'dan } \\
\text { olmayan } \\
\text { Topluluk } \\
\text { Ulusal olmayan } \\
\text { Zayıf } \\
\text { Fakirlik } \\
\text { Itibarsız } \\
\text { Gösterişsiz }\end{array}$ & $\begin{array}{l}\text { Danimarkalı } \\
\text { Toplum } \\
\text { Ulusal } \\
\text { Güçlü } \\
\text { Zenginlik } \\
\text { Saygın } \\
\text { Gösterişli }\end{array}$ & $\begin{array}{c}\text { Amalienborg } \\
\text { Sarayları, kraliyet } \\
\text { ve devlet } \\
\text { sarayları, kültürel } \\
\text { miras alanlarını } \\
\text { ziyaret etmek ve } \\
\text { bu alanlardaki } \\
\text { milli değerlere } \\
\text { saygı duymak, } \\
\text { onurlanmak }\end{array}$ & Ulusalcılık miti & İşlevsel \\
\hline Dallabona (2015) & $\begin{array}{l}\text { İtalya temalı lüks } \\
\text { Hotel Missoni } \\
\text { Edinburgh ve } \\
\text { Maison Moschino } \\
\text { otel temsilleri }\end{array}$ & İşletme & $\begin{array}{l}\text { İtalyan olmayan } \\
\text { (moda, ürünler, } \\
\text { gastronomi } \\
\text { unsurları) }\end{array}$ & $\begin{array}{l}\text { İtalyan olan } \\
\text { (moda, ürünler, } \\
\text { gastronomi } \\
\text { unsurları) }\end{array}$ & $\begin{array}{l}\text { İtalyan modası } \\
\text { temalı otellerde } \\
\text { kalarak lüks } \\
\text { İtalyan deneyimi } \\
\text { yaşamak } \\
\end{array}$ & $\begin{array}{c}\text { Ulusalculık (Italya) } \\
\text { miti } \\
- \\
\text { Tüketim miti }\end{array}$ & İşlevsel \\
\hline $\begin{array}{l}\text { Crăciunescu } \\
(2016)\end{array}$ & $\begin{array}{l}\text { Jamaika turistik } \\
\text { tanıtım afişleri }\end{array}$ & Destinasyon & $\begin{array}{c}\text { Benlik } \\
\text { Sömürgeci } \\
\text { Egzotik olmayan } \\
\text { Tüketen } \\
\text { Gelişmiş }\end{array}$ & $\begin{array}{l}\text { Ötekilik } \\
\text { Sömürülen } \\
\text { Egzotik } \\
\text { Tüketilen } \\
\text { Gelişmemiş }\end{array}$ & $\begin{array}{c}\text { Jamaika turistik } \\
\text { tüketim } \\
\text { deneyimleri }\end{array}$ & $\begin{array}{c}\text { Tüketim miti } \\
- \\
\begin{array}{c}\text { Postkolanyalizm } \\
\text { miti }\end{array}\end{array}$ & Eleştirel \\
\hline Banik (2017) & $\begin{array}{l}\text { Kuzey Doğu } \\
\text { Hindistan tanıtım } \\
\text { broşürleri }\end{array}$ & Destinasyon & $\begin{array}{l}\text { Tekdüze } \\
\text { Fakirlik } \\
\text { Çok bilinen } \\
\text { Hindistan } \\
\text { Modern } \\
\text { Yakın } \\
\text { Çirkinlik }\end{array}$ & $\begin{array}{c}\text { Çeşitlilik } \\
\text { Zenginlik } \\
\text { Çok fazla } \\
\text { bilinmeyen } \\
\text { Hindistan } \\
\text { Geleneksel } \\
\text { Uzak } \\
\text { Güzellik }\end{array}$ & $\begin{array}{c}\text { Bir destinasyon } \\
\text { olarak } \\
\text { Kuzey Doğu } \\
\text { Hindistan } \\
\text { temsilleri }\end{array}$ & $\begin{array}{c}\text { Keşfedilmemiş } \\
\text { cennet miti } \\
- \\
\begin{array}{c}\text { Postkolanyalizm } \\
\text { miti }\end{array}\end{array}$ & Eleştirel \\
\hline
\end{tabular}

Cilt 33 • Sayı 2 • Güz 2022 • 35 
rist davranışı bağlamında incelemesine örnektir. Barthes'in gösterge modeli izinde mitlerin, turist motivasyonlarını ve deneyimlerini şekillendirebileceğini ifade eden Johns ve Clarke (2001), İngiltere Norfolk Broads bölgesinde tekne gezisine katılan turistlerle yapılan çalışmalarında sıradan/ sıra dışı, sıkıcı/eğlenceli, aynılık/farklılık gibi karşıtlıklar temelinde öne çıkan nitelikleri barınd1ran ideal tekne turizmi deneyimlerinin mitleştirildiğini öne sürmektedir. Turistler bu deneyimlere ulaşma motivasyonu ile gezilere katılmaktadır. Johns ve Clarke'e (2001) göre turistler mitlere inandığı ölçüde mitler işlevsellik kazanır. Bu bağlamda turist davranışını anlama noktasında mitlerin başvuru noktası olduğu görülmektedir.

Knudsen vd. (2014), Barthes' in izinden giderek turistik alanlardaki ideolojik yerleştirmelere ilişkin dikkat çeken bulguları raporlamışlardır. Danimarka'da bulunan tarihi Frederiksstaden Bölgesi ve Amalienborg Sarayı örneğinde göstergebilimsel bir inceleme yapan Knudsen vd. (2014) bu destinasyonlarda ulusalcılık ideolojisine ilişkin çok sayıda sembol olduğunu kaydetmişlerdir. Çalışmaya göre bu kültürel miras alanlarındaki Danimarka kimliği ve kraliyete ait güç ve zenginlik göstergeleri ulusalcılık ideolojisini beslemektedir. Lévi-Strauss'a göre okunduğunda ulusal olmayan/ulusal, gösterişli/gösterişsiz, fakir/zengin gibi yapısal karşıtlıklar üzerinden Danimarka kimliğinin yüceltildiği, bu alanları ziyaret etmenin ise ulusalcıllk ideolojisini besleyeceği anlaşılmaktadır. Ayıca yazarlar, destinasyon kimliği ve imajı geliştirme konusunda sembolik anlam inşa etme süreci olarak mitlerin işlevselliğine dikkat çekmektedir. Dolayısıyla çalışma turizm mitlerinin işlevsel yorumuna bir örnek olarak kaydedilmiştir.

Ulusal kimliğin öne çıktığı bir başka çalışmada Dallabona (2015), Birleşik Krallık'ta bulunan lüks İtalyan modasını tema alan iki farklı otel işletmesinin marka temsillerine odaklanarak bir toplumsal göstergebilim araştırması yürütmüştür. İtalyan olan/İtalyan olmayan karşıtlığı üzerinden geliştirilen sembolik anlatımlarla İtalyan ulusal kimliğinin, pazarlama söylemleriyle mitleştirildiğini ifade eden Dallabona (2015), bu mit oluşturma sürecinin küyerelleşme (glocalisation) kapsamında rekabetteki işlevselliğine dikkat çekmek- tedir. Lévi-Strauss'a göre okunduğunda otellerin, İtalya'ya özgü lüks değerlerle ayrıcalıklı bir deneyim vaat ettiği anlaşılmaktadır. Çalışma ulusal kimlik mitinin, turizm pazarlamasındaki araçsal rolüne işaret etmektedir. Bu bakımdan mitlerin kavramsallaştırılmasında işletmeler açısından işlevsel bir yaklaşım izlendiği görülmektedir.

Bir başka araştırmada Kane (2013) Yeni Zelanda örneğinde alanlarında tanınmış ve öncü olan maceracıların söylemlerini konu edinmiştir. Macera turizm pazarı için bir çeşit kanaat önderi olarak tanımlanabilecek bu bireyler, imkânsız görünen riskli, zor, beceri gerektiren faaliyetleri tamamlayarak alanlarında ün yapan kişilerdir. Yazara göre bu kişiler, imkânsız denebilecek macera deneyimlerini başarıyla yapabildikleri için söz konusu macera deneyimlerinin erişilebilir olduğunu ya da yapılabileceğini göstermektedir. Lévi-Strauss'a göre okunduğunda sıradan/sıra dışı, imkânsız/mümkün gibi karşıtlıklar arasındaki çelişkiyi giderecek şekilde bu maceraperest öncülerin, erişilebilir bir macera turizmi deneyimini mitleştirdiği anlaşılmaktadır. Bu bağlamda bu çalışmanın da mitlerin işlevsel yorumuna örnek teşkil ettiği belirtilebilir.

Nelson (2005) ise destinasyon pazarlamasında mitlerin analizine ilişkin örnekler sunmaktadır. Karayipler'de bir ada ülkesi olan Greneda'nın tanitım materyalleri üzerinde insanlar, yer ve doğa bağlamında göstergebilimsel incelemeler yapan Nelson (2005), turist bakışına göre öteki/öteki olmayan, tanıdık/egzotik gibi yapısal karşıtlıklar temelinde Greneda destinasyon temsillerinin mitleştirildiğini öne sürmektedir. Ülkede turizm sisteminin Avrupalılara bağlı olmasından dolayı neokolonyalizm ideolojine ilişkin bazı ipuçları sunmakla birlikte yazar, çalışmanın genelinde mitlerin turistik tanıtımlardaki işlevlerine ilişkin çıkarımlar sunmaktadır.

Benzer bir çalışma Waitt ve Head (2002) tarafından Avustralya Kimberley'de yapılmıştır. Çalışmada turistlerden bölgeyle ilgili kartpostalları okumaları istenmiştir. İnsan/hayvan, yakın/uzak, uygar/vahşi gibi karşıtlıklar temelinde okunduğunda ilkellik ve ötekilik gibi anlamlara sahip bu destinasyon yazarlara göre turistlerce "son sınır (frontier) destinasyon" şeklinde mitleştirilmek- 
tedir. Çalışmaya göre turizm uygulayıcıları ve politikacılar tarafından tasarlanan bu kartpostallar, uçsuz bucaksız ve sahipsiz toprakları, egzotik ve macera dolu deneyimler vaat eden bir mite dönüştürmektedir. Ancak bu temsiller bölgenin yerel halkı Aborijinlerin haklarının teslim edilmesi bağlamında sorunlara işaret etmektedir. Buna göre kartpostallarla kamuya açı coğrafi bir tahayyül yaratılarak Aborijin halkının, topraklarıyla olan bağlantısının kesilmesine hizmet edecek bir alg1 yaratılması söz konusudur. Bu durumu Aborijin temsillerinin ve haklarının sömürüsü şeklinde yorumlayan yazarlar, bu örnek üzerinden neokolonyalizm ideolojisinin turistik kartpostallarla üretilebileceğini öne sürmektedir. Buna göre Waitt ve Head'ın (2002) bu çalışmasının neokolonyal ideolojiyi işaret eden eleştirel bir yaklaşım izlediği görülmektedir.

Banik (2017) güvenlik kaygılarıyla uzun bir dönem kapalı kalan Kuzey Doğu Hindistan bölgesinin turizme kazandırılmasında yürütülen tanıtım kampanyasının broşürleri üzerine göstergebilim yöntemiyle bir inceleme yapmıştır. Buna göre bölgenin halihazırda bilinen Hindistan'dan ne denli farklı, zengin, uzak, güzel, egzotik olduğu gibi özellikleri anlatılarak keşfedilmeyi bekleyen bir cennet miti ile tanıtıldığı sonucuna ulaşımıştır. Dahası yazara göre keşfedilmemiş cennet mitinin gerisinde postkolanyalizm ideolojisi yer almaktadır. Dolayısıyla bu çalışmanın eleştirel bağlamda turizm mitlerine ilişkin örnek teşkil ettiği söylenebilir.

Crăciunescu (2016) turizmin, postkolonyal ilişkilerle gömülü olduğu ve postkolonyalizmi güçlendirdiğini öne sürerek, postkolonyal söylemlerin ortaya çıarılmasında yöntemsel yaklaşım olarak göstergebilimi önermektedir. Jamaika turizm görselleri üzerinde inceleme yapan Crăciunescu'a (2016) göre postkolonyal toplumlarda sunulan egzotik turistik deneyimler temelde tüketim deneyimidir ve benlik/ötekilik, batı/ doğu, sömürgeci/sömürülen yapısal karşıtlıkları üzerinden yorumlanabilir. Tüketim ve postkolonyalizm ideolojisine ilişkin çıkarımlar yapıldığından bu çalışmada da eleştirel yaklaşım izlendiği kaydedilmiştir.
Turizm mitlerinin kullanımına ilişkin göstergebilim yöntemiyle kanıtlar sunan ilk çalışmalardan biri, Hopkins'e (1998) aittir. Huron Gölü/ Kanada destinasyonuna ilişkin tanıtım materyallerini inceleyen Hopkins'in (1998) çalışmasına göre materyallerde kent/kır, yapay çevre/doğal çevre, hızlı/yavaş, yerel olmayan/yerel gibi karşıtlıkları temelinde anlamlar inşa edilmektedir. Örneğin topluluk ve toplum, sirasıyla kır ve kent yaşamındaki sosyal ilişkilerin ifadesidir. Bunlardan ilki, gerçek ve organik yaşamı anlatan, topluluk (gemeinschaft) diğeri ise hayali ve mekanik bir yapıyı ifade eden toplumdur (gesellschaft) (Tönnies 1955). Buna göre karşıtlıkların yarattığ 1 gerilimi gidermek üzere Huron Gölü, ayrıcalıklı bir kent sınıfı için rekreasyonel bir eğlence ortamı sunmaktadır. Kent yaşamından, kentin yapay çevresi, hızı ve sunduğu yüzeysel ilişki atmosferine karşın destinasyon, kırsal doğal güzellikler, eşsiz deneyimler, sakinlik ve dinginlik, aile ve komşuluk gibi yakın ilişkiler sunmaktadır. Burada kentli insanlara, kırsal turizm faaliyetlerine katılarak şehirde kendi ortamlarında yaşadıkları gerilimi azaltan doğaya dönük ve özgün deneyimler vaat edilmektedir. Çalışmanın bulguları Lévi-Strauss'a göre okunduğunda, kent yaşamına ilişkin olumsuzlara karşı kır yaşamına ilişkin olumlu anlamların yüceltildiği ve "özgün kırsal turizm deneyimlerinin" mitleştirildiği anlaşılmaktadır. Hopkins (1998) eleştirel bir yaklaşım izleyerek kırsal turizm etkinliklerine katılmanın özünde bir turistik deneyim tüketimi olduğuna dikkat çekmekte ve "özgün kırsal turizm deneyimi" mitinin tüketimciliğe hizmet ettiğini belirtmektedir.

\section{SONUÇ VE DEĞERLENDIRME}

Çalışmada turizmle ilgili olay ve olguları anlamlandırmak için bir başvuru kaynağı olarak mitler tartışmaya açılmıştır. İncelenen araştırmalarda, çok farklı ve çeşitli konularda, yoruma dayalı olarak sunulan turizm mitlerine ilişkin bulgular, bu çalışmada ortak bir çerçevede bir araya getirilerek sunulmuştur. Çalışma turizmde mitlerin anlamlandırılması ve çözümlenmesine ilişkin alınyazındaki temel yaklaşımlara ilişkin çıkarımlar sunmaktadır. Buna göre alanyazında 
turizm mitlerinin işlevsel yaklaşım ve eleştirel yaklaşım bağlamda kavramsallaştırılabileceğ $\mathrm{i}$ görülmüştür.

Ilk olarak eleştirel yaklaşım bağlamında turizm mitlerinin, turizm endüstrisinin turistik tüketimleri doğallaştırmak üzere ürettiği ve neoliberalizm ideolojisine dayanan söylemler içerebildiği görülmektedir. Bu görüşe göre sermayedar işletmeler, tüketici turistler ve yerel halkın taraf olduğu çatışma durumlarında, mitler çoğunlukla işletmelerce yaratılmış ve işletmelerden yanadır. Özellikle sürdürülebilir turizm kalkınmasıyla net bir biçimde çelişik görülen bu neoliberal tüketim mitleri eleştirel çalışmalara konu olmaktadır. Ayrıca postkolonyalizm ve/veya neokolonyalizm ideolojileri de turizm mitlerinde görülebilmektedir. Buna göre eleştirel yaklaşım içinde turizm mitleri, sömüren/sömürülen, gelişmemiş/ gelişmiş ilkel/uygar gibi derin yapısal karşıtlıkları normalleştirmek üzere otantik turizm deneyimlerinin vaat edildiği ve postkolonyalizm ve/ veya neokolonyalizm ideolojilerinin beslediği bir turistik söylem olarak okunabilir.

İkinci olarak işlevsel bağlamda turizm mitlerinin destinasyon pazarlama, imaj geliştirme, turist davranışını anlama gibi konularda hizmet ettiği söylenebilir. Buna göre turizm pazarlamasında mitlerin kullanılması -bir diğer ifadeyle kültürel bağlamda tüketicilere hitap edecek yananlamların dahil edilmesi- etkili bir pazarlama iletişimi yöntemi olarak tanımlanmaktadır. Dahası bu yaklaşıma göre turist davranışının açıklanmasında da mitsel çözümlemelere başvurulabileceği anlaşılmaktadır.

Turist davranışı açısından bakıldığında mitler, bir yer değiştirme eylemi olarak turizm hareketliliğinin psikolojik ve sosyal boyutlarda beklenen deneyimsel çıtılarıyla ilgilidir. Burada turizm hareketliliği, endüstriyel aktörler tarafından kurgulanan bir ekonomik olaydan ziyade yer değiştirme eylemiyle ortaya çıkan potansiyel bir zihinsel durumu ifade etmektedir. Bu açıdan incelendiğinde turizm mitleri, Lévi-Strauss'un mit kavramsallaştırılmasına daha çok yaklaşmaktadır. Kendi işleyişini gizleyen ve anlamlarını doğalmış gibi sunan bir mit anlayışı yerine Lévi-Strauss'a göre mitlerin işleyişi açıktır, sade- ce bir sınıfın değil tüm toplumun ya da insanl1ğın endişelerini giderme rolü üstlenebilir (Fiske 1996). Turist davranışındaki mitlere bakıldığında temel karşıtlıkların insanlık, doğa ya da yaşamla ilgili soyut yapılarla ilgili olduğu görülmektedir. Gros'un (2017) doğa yürüyüşlerinde var olduğunu iddia ettiği yenilenme veya arınma miti buna örnek gösterilebilir. Anlaşılacağı üzere burada sinıfsal karşıtlıklardan farklı olarak ölüm/yaşam ya da yok oluş/varoluş gibi tüm insanlığı ilgilendirebilecek soyut yapılar arasındaki karşıtlıklar söz konusudur. Temelde de turizm ve rekreasyon etkinlikleri doğrudan insanların iyi oluşuna hitap etmektedir. Elbette turist davranışını açıklayabilen mitlerin, pazarlama faaliyetlerinde tüketici davranışı kapsamında dikkate alınması söz konusu olabilir. Ancak sadece ekonomik bir olay olarak değil, sosyo-kültürel ve hatta çevresel bir olay olarak turizm ilişkilerinin açılanabilmesinde mitler katkı sağlayabilir.

Sosyal, psikolojik ve fizyolojik işlevlerine bakıldığında mitler, abartı ya da kandırmaca gibi olumsuz anlamlardan çok daha fazlasını işaret eder. Dahası her mit aynı zamanda karşıt bir mit barındırır (McKercher ve Prideaux 2014). Örneğin "turizm çevreyi tahrip eder" ve "turizm çevreyi korur" mitleri karşıt iki miti oluşturmaktadır. Karşıt mitler çalışma alanının çok disiplinli epistemolojik gelişimini teşvik eden verimli bir araştırma gündemi sunmaktadır. Bu bağlamda mitlerin turizm akademisi için yeni tartışma alanları sunacağı açıktır.

Eleştirel yaklaşıma, çoğunlukla işletmecilik disiplininden beslenen turizm alanyazınında sıklıkla rastlanmamaktadır. Ancak turizm yukarıda da ifade edildiği üzere işletme sınırlarının ötesinde sosyal bir olay olduğundan, kültür teorileri ve ekonomi-politik teorileriyle temellendirilmiş çalışmalarla yeni tartı̧̧ma konuları açılabilir. Özellikle neoliberalizm ve tüketimcilik üzerine görgül kanıtlarla desteklenebilecek çalışmalara ihtiyaç vardır. Bu noktada ideolojilerin somutlaştırılması ve tartışma zemini yaratma bağlamında mit çözümlemeleri önemli bir yöntemsel yaklaşım olacaktır.

Çalışma, tarama sırasında ulaşılabilen makalelerle sınırlıdır. Ayrıca bilgisine ulaşılan turizm 
mitleri, sistematik bir sunuş sağlayabilmek için Lévi-Strauss'un yaklaşımı kapsamında temellendirilmeye çalışılmıştır. Lévi-Strauss'un modeli yanı sira Barthes (2005) ya da Chapman (1986) modelleri de mit analizlerinde kullanılabilir. Mitlerin bilimsel ve sistematik bir şekilde çözümlenmesinde göstergebilim yöntemi önemli bir başvuru kaynağıdır. Gelecek çalışmalarda sadece pazarlama materyalleri değil, turistik değerler, objeler, coğrafi unsurlar ve hatta kişiler ve topluluklar bazında mit çözümlemeleri yapılabilir.

\section{KAYNAKÇA}

Banik, S. (2017). Stereotyping India's North East: Examining the in Tourism Discourse, Rupkatha Journal on Interdisciplinary Studies in Humanities, 9 (3): 210-216.

Barthes, R. (2003). Çağdaş Söylenler. (Çev: T. Yücel). İstanbul: Metis Yayınları.

Barthes, R. (2005). Göstergebilimsel Serüven. (Çev: M. Rifat ve S. Rifat). İstanbul: Yapı Kredi Yayınları.

Berger, A. A. (2011). Tourism as a Postmodern Semiotic Activity, Semiotica, 2011 (183): 105-119.

Bennett, A. (2013). Kültür ve Gündelik Hayat. (Çeviri: N. Tokdoğan, B. Şenel ve U. Y. Kara, T.). Ankara: Phoenix.

Campbell, J. (1991). The Power of Myth. New York: Anchor Books.

Chapman, S. (1979). Advertising and Psychotropic Drugs: The Place of Myth in Ideological Reproduction, Social Science \& Medicine. Part A: Medical Psychology \& Medical Sociology, 13: 751-764.

Chapman, S. (1986). Great Expectorations: Advertising and the Tobacco Industry. Londra: Comedia Pub.

Crăciunescu, A. (2016). On Methodology and (Post) Colonialism in Tourism Promotional Language, AlmaTourism, (Özel Sayı N. 5): 125-133.

Dağtaş, B. (2012). Reklamı Okumak. Ankara: Ütopya Yayınları.

Dallabona, A. (2015). Luxury Fashion Flagship Hotels and Cultural Opportunism: The Cases of Hotel Missoni Edinburgh and Maison Moschino, Hospitality and Society, 5 (2-3):117-143.

Erdoğan, İ. (2010). Ekoturizmin Eleştirel Bir Değerlendirmesi. İçinde; Orman Ekosistemlerinde Ekoturizm Çalıştayı ve 10. Yılında TODEG (ss. 65-83). Ankara: Türkiye Ormancılar Derneği.

Fiske, J. (1996). İletişim Çalışmalarma Giriş. (Çev: S. İrvan). Ankara: Ark Yayınları.

Greimas, A. J. (1989). On Meaning, New Literary History, 20 (3): 539-550.

Gros, F. (2017). Yürümenin Felsefesi. (Çev: A. Ulutaşl1). İstanbul: Kolektif Yayınları.

Hopkins, J. (1998). Signs of the Post-Rural: Marketing Myths of a Symbolic Countryside, Geografiska Annaler: Series B, Human Geography, 80 (2):65-81.
Horzum, I. (2011). Reklamlarda İslenen Modern Mitler ve Yeşil Mitin Göstergebilimsel İncelemesi, E-Journal of New World Sciences Academy, 6 (1): 30-41.

Johns, N. ve Clarke, V. (2001). Mythological Analysis of Boating Tourism, Annals of Tourism Research, 28 (2): 334-359.

Kane, M. J. (2013). New Zealand's Transformed Adventure: From Hero Myth to Accessible Tourism Experience, Leisure Studies, 32 (2): 133-151.

Knudsen, D. C., Rickly-Boyd, J. M. ve Greer, C. E. (2014). Myth, National Identity, and The Contemporary Tourism Site: The Case of Amalienborg and Frederiksstaden, National Identities, 16 (1): 53-70.

König, J. C. L., Wiedmann, K.-P., Hennigs, N. ve Haase, J. (2016). The Legends of Tomorrow: A Semiotic Approach Towards a Brand Myth of Luxury Heritage, Journal of Global Scholars of Marketing Science, 26 (2): 198-215.

Lévi-Strauss, C. (1962). La Pensée Sauvage. Paris: Plon.

Lévi-Strauss, C. (2013). Mit ve Anlam. (Çev: G.Y. Demir). İstanbul: İthaki Yayınları.

Lyons, K., Hanley, J., Wearing, S. ve Neil, J. (2012). Gap Year Volunteer Tourism. Myths of Global Citizenship?, Annals of Tourism Research, 39 (1): 361-378.

MacCannell, D. (1987). Marketing and Semiotics:'Sex Sells': Comment on Gender Images and Myth in Advertising. Mouton: De Gruyter.

Malinowski, B. (1926). Myth in Primitive Psychology. Londra: Kegan.

McKercher, B. ve Prideaux, B. (2014). Academic Myths of Tourism, Annals of Tourism Research, 16: 16-28.

Nelson, V. (2005). Representation and Images of People, Place and Nature in Grenada's Tourism, Geografiska Annaler, Series B: Human Geography, 87 (2): 131-143.

Parladır, H. S. (2006). Mit Simgeciliği ve Mitin Yapısal Çözümlemesi, Folklor/Edebiyat Dergisi, 4 (12): 1-19.

Sharpley, R. (2010). The Myth of Sustainable Tourism. CSD Working Papers Series 4: 1-14 2009/2010, http://www.uclan.ac.uk/schools/built_natural_environment/research/csd/fi les/CSD_Working_Paper_4_Sustainable_Tourism_Sharpley.pdf, Erişim tarihi, 4 Mart 2020.

Tresidder, R. (2011). The Semiotics of Tourism. İçinde; P. Robinson, S. Heitmann ve P. Dieke (Editörler) Research Themes for Tourism (ss.59-69). Cambridge: CABI Publishing.

Tönnies, F. (1955). Community and Association:(Gemeinschaft und Gesellschaft). Londra: Routledge.

Turner, V. W. (1969). The Ritual Process: Structure and AntiStructure. Londra: Routledge.

Türk Dil Kurumu. (2021). Türk Dil Kurumu: Sözlük: Mit. Türk Dil Kurumu Sözlükleri Resmi Web sitesi, https:// sozluk.gov.trl, Erişim tarihi: 10 Ağustos 2021.

Urbain, J. (2009). Yolcu ve İkizi “Sahte" Karmaşası, Cogito Turist: Modern Çağın Seyyahı, 59: 67-80.

Urry, J. (2009). Turist Bakışı. Ankara: Bilgesu Yayıevi.

Waitt, G. ve Head, L. (2002). Postcards and Frontier Mythologies: Sustaining Views of The Kimberley as Timeless, Environment and Planning D: Society and Space, 20 (3): 319-344.

Yücel, T. (2005). Yapısalcılık. İstanbul: Yapı Kredi Yayınları. 


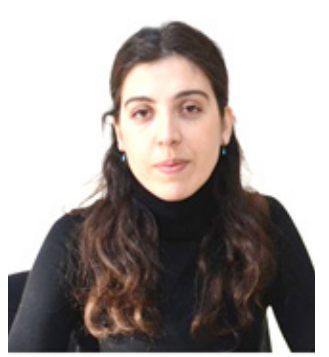

Kübra AŞAN

Gazi Üniversitesi Ticaret ve Turizm Eğitim Fakültesi'nden Konaklama Işletmeciliği Bölümü’nden mezun oldu (2010). Yüksek lisans ve doktora derecesini Anadolu Üniversitesi'nden Turizm İşletmeciliği Dalı'ndan aldı (2013/2018). Anadolu Üniversitesi'nde çalışmaya başladı (2010). Sinop Üniversitesi Turizm İşletmeciliği ve Otelcilik Yüksekokulu'nda görev yapmaktadır (2018-). Temel çalışma alanları, turist davranışı, açık alan rekreasyonu, sürdürülebilir turizm ve etkinlik yönetimidir. 